\title{
The Historical Impacts of Hydroelectric Power Development on Traditional Mountain Irrigation in the Valais, Switzerland
}

\author{
Author(s): Darren S. Crook \\ Source: Mountain Research and Development, 21(1):46-53. 2001. \\ Published By: International Mountain Society \\ DOI: http://dx.doi.org/10.1659/0276-4741(2001)021[0046:THIOHP]2.0.CO;2 \\ URL: http://www.bioone.org/doi/full/10.1659/0276-4741\%282001\%29021\%5B0046\%3ATHIOHP \\ $\% 5 \mathrm{D} 2.0 . \mathrm{CO} \% 3 \mathrm{~B} 2$
}

BioOne (www.bioone.org) is a nonprofit, online aggregation of core research in the biological, ecological, and environmental sciences. BioOne provides a sustainable online platform for over 170 journals and books published by nonprofit societies, associations, museums, institutions, and presses.

Your use of this PDF, the BioOne Web site, and all posted and associated content indicates your acceptance of BioOne's Terms of Use, available at www.bioone.org/page/terms of use.

Usage of BioOne content is strictly limited to personal, educational, and non-commercial use. Commercial inquiries or rights and permissions requests should be directed to the individual publisher as copyright holder. 


\section{The Historical Impacts of Hydroelectric Power Development

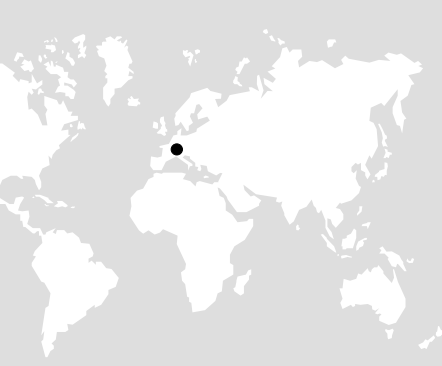

In many Western European mountains, ancient irrigation practices have been the basis for sustainable subsistence-based mountain agriculture, especially up to the beginning of the 20th century. These mountain zones have

proved popular sites for the development of hydroelectric power (HEP). Few attempts have been made to measure the impact of HEP on traditional indigenous irrigation systems dependent on the same resource base. This article examines the physical and socioeconomic impact of HEP development on the bisse irrigation system in the Valais, Switzerland, and discusses new water resource issues, conflicts, adaptations, and innovative responses. The study shows that a two- to three-tier consultation process has led to communes and autonomous collective irrigation institutions (consortages) signing and ratifying long-term conventions that ceded water to HEP companies at the scale of watersheds. Water supplies for irrigation are protected by these conventions at the same time as changed hydrological regimes improve water security in economically viable bisses. Conventions also improved the economic security of some consortages, while at the level of individual households, HEP development allowed diversification of income generation strategies.

Keywords: Hydroelectric power; bisse irrigation; consortage; adaptation; innovation; Valais; Switzerland.

Peer reviewed: September 2000. Accepted: October 2000.

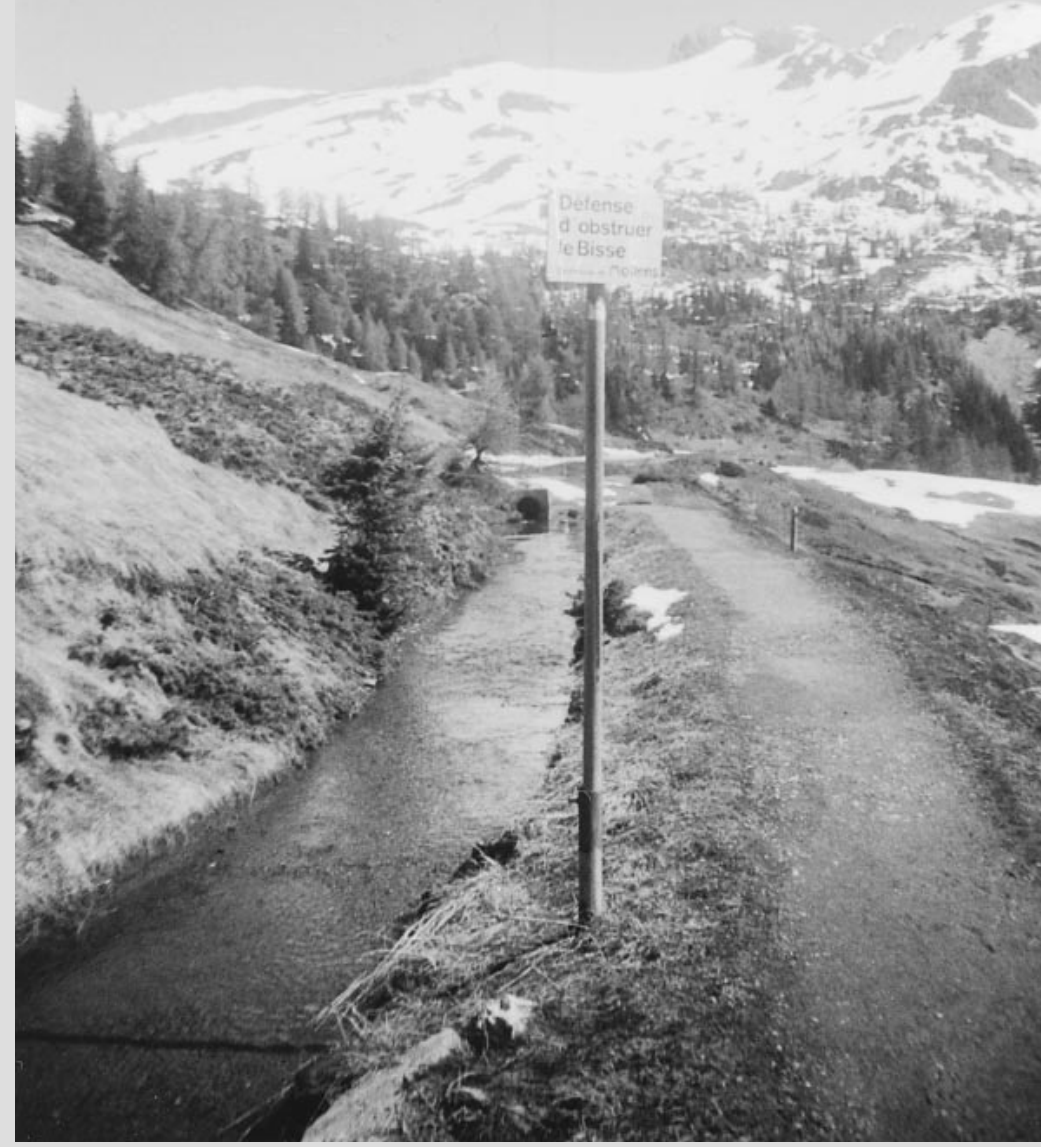

FIGURE 1 An open bisse or irrigation channel that conveys water for summer pastureland in the highly developed agricultural and tourist area of Montana-Aminona, Canton of Valais. Translated into English, the sign reads "Obstructing the bisse is prohibited." (Photo by author)

\section{Introduction}

At the beginning of the 20th century, a network of ancient irrigation systems existed throughout the European Alps (Carrier 1932); in many places, it formed the basis for sustainable subsistence-based mountain agriculture. Later in the century, the hydrological catchment areas for these systems became popular sites for the development of hydroelectric power (HEP). Thus, traditional indigenous irrigation systems and HEP became dependent on the same resource base and traditional users had to coexist with modern users. Changes in the natural hydrological regimes of mountain rivers impacted on existing ecosystems and created new water resource issues. While the environmental, socioeconomic, and geopolitical impacts of HEP development are well documented (Tung 1998; Reynard 1999; Salman and Uprety 1999), the impacts on traditional irrigation systems located in the mountain catchment are poorly understood.

This article examines the physical and socioeconomic impacts of HEP development on the bisse irrigation system in the Valais, Switzerland. It focuses on the effects HEP development has had on locally governed bisse irrigation associations (consortages), describing and evaluating the adaptations and innovations that have occurred. The article explores emerging water resource issues and areas of conflict (legal discourse, hydrological 
FIGURE 2 Location map showing the Grande Dixence scheme and its sphere of influence. (Maps by Andreas Brodbeck)

change, governance, restructuring of organization and management, economic adjustment, and innovation) from the perspective of the consortage. It concludes with a brief overview of HEP development and its implications for future mountain irrigation strategies and sustainable development in mountain environments.

\section{Bisse irrigation}

Low rainfall (an average of $602 \mathrm{~mm} / \mathrm{y}$ for 1901-1993), high temperatures, and evaporation in the summer months, particularly in the Rhône Valley, create a water deficit of around 70-96 $\mathrm{mm}$ for the months of May-August (Reynard 1995). During this period, around $2.3-3 \mathrm{~mm}$ of irrigation water is required to offset evapotranspiration losses from plants. Thus, local communities in the Valais, like people in other dry areas of the European Alps (eg, Maurienne, Aosta, Tyrol, Engadine, Grisons), constructed slope offtake irrigation systems to support vertically organized agropastoral systems (Netting 1981; Crook 1997). Water is conveyed over long distances $(1-32 \mathrm{~km})$ in open channels (Figure 1) to village lands at the heads of interfluves, where it is then distributed traditionally under gravity onto pastureland and other crops, such as vines and fruit trees grown at various altitudes (Crook and Jones 1999b). Knowledge about the genesis of the bisse system remains vague, but irrigation channels were built some time around the 11th century (Liniger 1980). There is no evidence to suggest that bisses were part of a planned large-scale development.

Over time, the water rights of feudal lords were conferred to newly formed consortages that developed to meet the subsistence needs of a burgeoning population. The consortages set about extending and modernizing the system by constructing new bisses or improving and enlarging existing ones, principally from the 14th to the 15 th century (Crook and Jones 1999b). These changes often led to conflicts over water rights that at times required external arbitration (Bratt 1995; Crook 1997). However, continuity in governance and organization over a period of 500-600 years have led to institutionalization of successful conflict resolution practices. The traditional system of irrigation was modernized at the turn of the 20th century, along with wider structural changes to the predominantly agricultural economy (Loup 1965; Jones et al 1998; Crook and Jones 1999a,b). Starting around the 1930s, two main technical innovations had a huge impact on the bisses. These were the introduction of spray irrigation and the construction of underground irrigation networks; also involved was a process of land consolidation and redistribution (Crook and Jones 1999b). Thus, it is important to emphasize that changes to the bisse system relating to HEP were but one facet of a wider process of structural adjustment to the local economy.

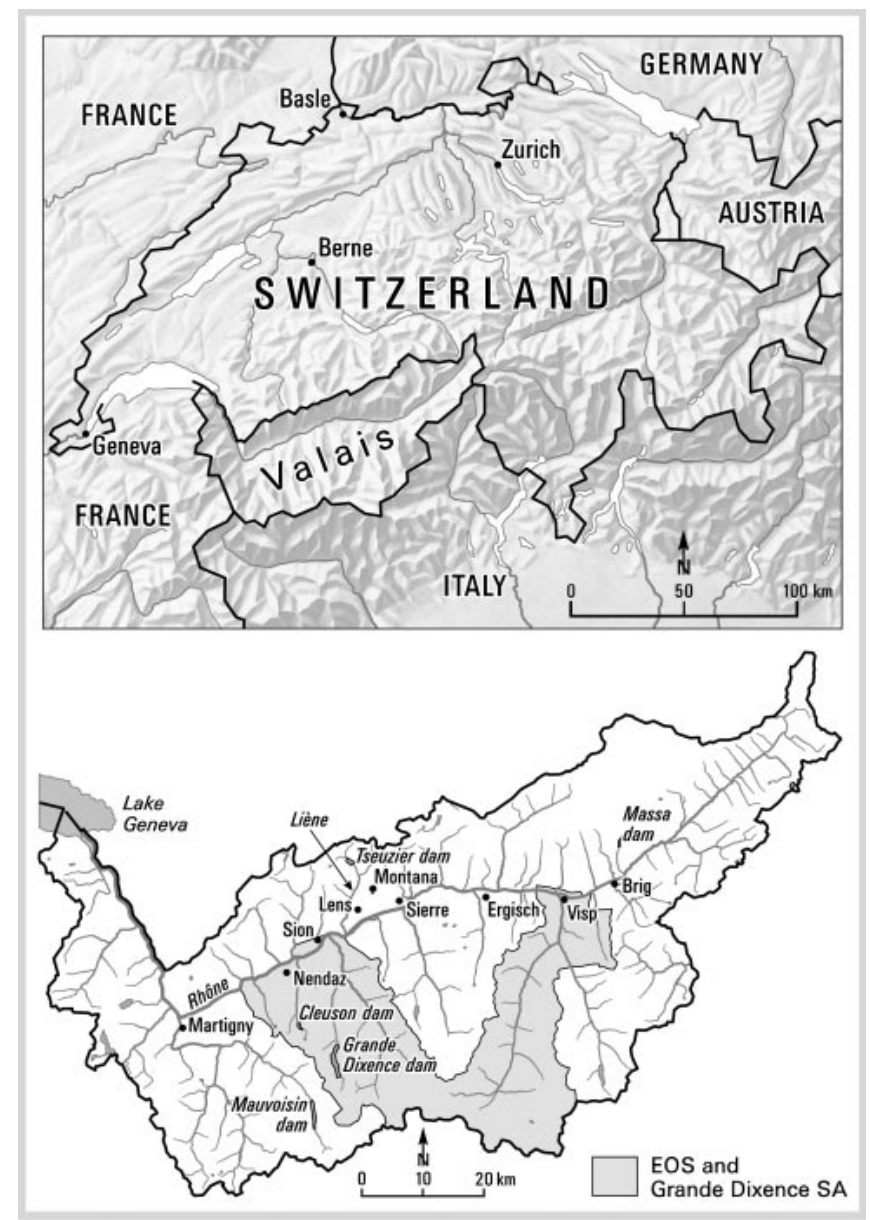

HEP generation started in Western Europe as of 1869 (Veyret 1970) and spread throughout the world during the 20th century. A large supply of water is required to create greatest efficiency in HEP generation. In the Valais, despite the water deficit in summer, the area's mountainous topography and high levels of orographic precipitation have been ideal for developing the Swiss HEP resource potential. The first HEP development in the Valais was at MartignyBourg in 1908 (Energie de l'Ouest-Suisse 1995). In 1948, 23 communes provided concessionary signatures for the construction of the Grande Dixence dam between 1950 and 1965 (Falcinelli, personal communication). This construction is part of a larger HEP scheme that culminated after the fourth extension project (Bieudron power station) in October 1998 (Bonifay 1997). Énergie de l'Ouest-Suisse (EOS) is the principal stakeholder in the Grande Dixence S.A., which collects glacial and snow meltwaters from the major lateral valleys south of the Rhône (Figure 2). Small single watershed HEP schemes are also found on the southern slopes of the Bernese Oberland. The Grande Dixence S.A. supplies around 15\% of Switzerland's electricity production (Falcinelli, personal communication). 
TABLE 1 Sources and methods of study.

\begin{tabular}{|l|}
\hline Impact \\
\hline Legal \\
\hline Governance/organization \\
\hline Physical (quantity) \\
\hline Physical (quality) \\
\hline Operational management \\
\hline Economic \\
\hline
\end{tabular}

\section{Evidence}

HEP conventions; solicitors' reports; EOS

Changes to consortage statutes and regulations; council or committee minutes and members

Hydrological and sedimentary change; infiltration and drainage losses

Water and soil quality

Regulations and rules; changes to scheduling and allocation of water

Consortage and communal accounts; land improvements service
Methods of study

Content analysis, interview

Archive analysis, in-depth interviews

Hydrological survey of channel discharge, infiltration, and leakage; sediment trap

Water/soil chemical analysis

Archive analysis; observation, interview, and questionnaire survey

Content analysis, interview

\section{Methodology}

The present study is based on interdisciplinary research conducted between 1994 and 1997, which incorporated a number of hydrological, social, and historical research activities (Table 1). The research identified and investigated the different facets of HEP generation that impacted on traditional irrigation systems through case studies of bisses on the Lens, Nendaz, and Briey plateaus. This study took into account environmental, technical, and cultural distinctions. It also investigated key events during the development of the bisse system and provided indicators for sustainable features within the system (Crook 1997). For the current article, data from further sources have been added and results compared to investigate the current status of the bisse system.

\section{Results}

\section{Legal conventions}

In most places, the drafting of HEP conventions involved a two- to three-tiered process of consultation at the level of the watershed. The first consultation between existing holders of water rights clarified ownership and use. The second consultation involved a cartel/consortium of the holders of these rights and an HEP company. Sometimes a third consultation process occurred between EOS and another HEP service provider seeking agreement to supply water to irrigators.

In the first instance, the historical boundaries of communities were often disputed, requiring a long, drawn-out conflict resolution process as solicitors searched for older documentary evidence to establish senior land and water rights at courts and tribunals before legal settlement. Usually, the riparian and usufructuary holders of ancient bisse water rights were bourgeois councils (composed of direct descendants of the original or early members of a community) or con- sortages, with the former transferring political and legal power to communal councils in the 19 th century. Intergenerational continuity and perceived fairness in governance and organization made these structures robust, generating an institutional capacity for flexibility, adaptability, innovation, and opportunity (Crook 1997). There was much overlap between representation on commune councils, consortage committees, and HEP company executives (Crook 1997). Thus, endogenous institutions were strengthened by insider knowledge, which created confidence and prevented recourse to legal requirements during negotiations with the HEP companies. For their part, HEP companies understood and addressed the moral obligation to supply water to local communities and fully integrated them in a participatory appraisal of their water needs.

Examples: A total of 23 communes entered into a consultation process with subsidiaries of the Grande Dixence S.A. Consensus was achieved by communes and consortages ceding their rights to water without general concessions or rental charges in mutually acceptable ex gratia conventions (Reynard 1999; Falcinelli, personal communication). In contrast, the commune of Sion and some others signed a convention ceding water rights for electrical production on the River Liène for 80 or 99 years to another HEP company (consortage archives). Under this convention, based on cantonal laws dating from the 19th century (29 September 1891 and 27 May 1898), the HEP company agreed to supply water to bisses but with fiscal concessions to consortages. Another convention between the commune of Nendaz and the NESA S.A. demonstrates how a commune can negotiate on behalf of independent consortages for a fixed right to a predetermined annual volume of water after changes to river discharge resulting from dam construction (consortage archives). Finally, as of December 1998, changing water uses and needs have been addressed by EOS and the Grande Dixence S.A., while HEP conventions (concessions and charges) were rene- 
gotiated with communes and consortages. The results of this negotiation process, which terminated in July 2000, are not yet in the public domain (Falcinelli, personal communication).

\section{Hydrological changes}

In the 20th century, a few bisses have received water via HEP-instigated motorized pumping, usually connected to HEP installations, or from canals in the Rhône Valley. More typically, bisses rely on gravitational flow to convey water (see Figure 1).

The amount of water available in each hydrological catchment was initially estimated and conceded to EOS, with reserves being made available within these concessions to meet needs for drinking water and irrigation (Département de l'Environnement et de l'Aménagement du Territoire 1995). Bisse and HEP conventions set out the conditions for annual abstraction based on pre-HEP flow regimes, inter- and intraannual variations in stream discharges, and preexisting (priority follows seniority) and new (where surplus exists) irrigation demand. This resulted in the construction of new bisses and distribution systems as long as there was no damage to existing systems.

Examples: Thus, the supply of water to bisses differs for each catchment and each bisse within the catchment. For example, the convention between the HEP company EOS and the commune of Nendaz guarantees a discharge of $0.15 \mathrm{~m}^{3} / \mathrm{s}$ (consortage archives) in the Printse River during the irrigation period, while the Swiss government (Ministry of the Interior, 8 May 1950) fixed a reserve supply of $400 \mathrm{~L} / \mathrm{s}$ at the start of bisse division. From this figure, a maximum discharge was established for each bisse in accordance with predetermined ancient water rights (Table 2). The values in Table 2 represent a percentage of the potential maximum discharge in the Printse River (May, 40\%; June, 80\%; July, $80 \%$; August, $40 \%$; September, $30 \%$ ). Hence, peak irrigation demand (June and July) coincides with peak river discharge and HEP surplus (Crook 1997). In the event of disagreements, the Ministry of the Interior fixes the quantity and period of irrigation. When circumstances warrant it, EOS can reduce the volume of water for a limited period with authorization from the Ministry of the Interior. In the case of increased demand for water, the commune assures priority to bisses by submitting reports to EOS; however, wastage must be avoided (Council Minutes, 27 October 1986).

In the Liène catchment, several consortages have conventions with the La Lienne S.A. The construction of the Tseuzier dam in 1952 and river regulation meant that the original headworks for the Grand Bisse de Lens could not be guaranteed to work. Thus, the convention sought to safeguard the water rights of the consortage by pumping water from the Usine de la Croix storage lake to a point approximately $2.6 \mathrm{~km}$ from the main headworks on the bisse. The La Lienne S.A. supplies enough water (ie, a maximum of $300 \mathrm{~L} / \mathrm{s}$ ) to supplement the original headworks between 15 April and 31 September (ie, the maximum irrigation period) and $60 \mathrm{~L} / \mathrm{s}$ in the month of October, specifically for cattle. This bisse, however, rarely operates at these maximum discharge levels.

The demand for water in the Grand Bisse de Lens relates to the supply for the Lens, Lower-Chermignon, and Montana reservoirs that provide water for spray irrigation of vines. The amount of water required by the consortage is only a small percentage $(38 \%)$ of the actual amount of water (mean 590,218.5 L/s) available from the HEP suppliers (Figure 3). From 1986 to 1995, the average irrigation season of the Grand Bisse de Lens was 91 days, although the number of hours operated varies from season to season. The Bisse de Briey always opens on 1 May and closes on 31 August regardless of the operational period of the bisse because of the HEP convention (Crook 1997).

The introduction of river regulation for HEP development has also meant a change in the erosional and depositional nature of many streambeds. Glacial sediments traditionally lined and sealed bisse channels flowing over permeable rock (Crook 1997). Increased dam storage and sediment deposition in reservoirs have reduced the amount of sediment in bisse waters. In some places, additional measures such as channel lining are now required to prevent loss of water through infiltration (25-75\%) during conveyance (Michelet 1995; Crook and Jones 1999b).

\section{Governance, organization, and management}

Because water is supplied by HEP companies, there must be a liaison between the governing bodies of bisses (or at least the operational component of this arrangement, ie, the bisse guard) and the HEP company during

TABLE 2 Guaranteed bisse discharges

downstream of Beuson (Bisse Vieux archives).

\begin{tabular}{|l|c|c|}
\hline Bisse & $\begin{array}{c}\text { Discharge } \\
\text { (L/s) }\end{array}$ & $\begin{array}{c}\text { Annual discharge } \\
\text { (million } \mathbf{~ m}^{\mathbf{3}} \text { ) }\end{array}$ \\
\hline Vieux & 150 & 1.05 \\
\hline Milieu & 150 & 1.05 \\
\hline Dessous & 150 & 1.05 \\
\hline Salins & 100 & 0.7 \\
\hline Baar & 100 & 0.7 \\
\hline Brignon & 100 & 0.7 \\
\hline Other bisses & 100 & 0.7 \\
\hline Total & 850 & 5.95 \\
\hline
\end{tabular}


FIGURE 3 Annual available and

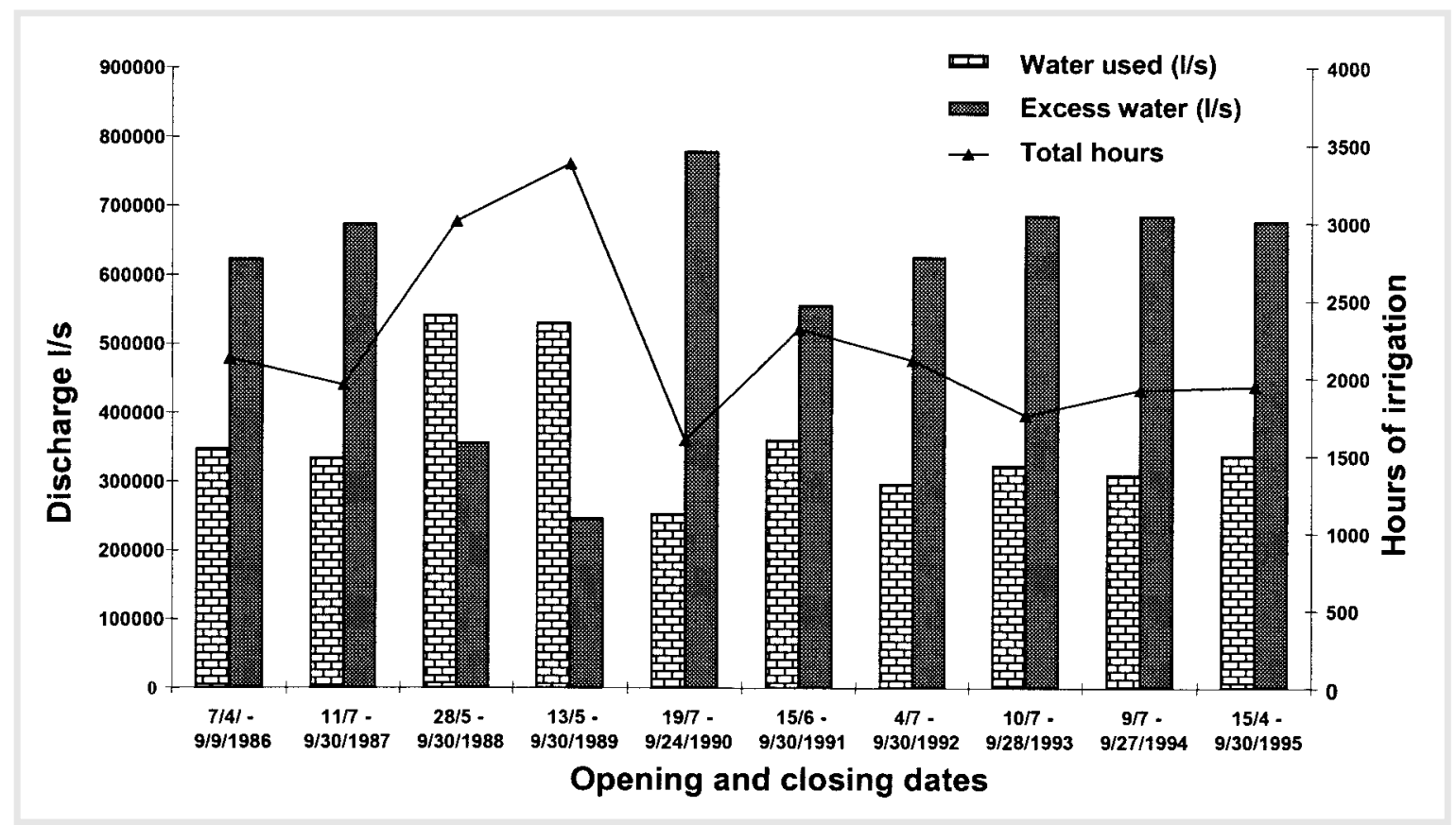

the irrigation season. One of the main functions of the guard is to regulate the discharge, either at the headworks or along the conveyance system. For example, the Bisse de Briey is opened by an HEP official who coordinates with the pumping station at Niouc using a walkietalkie to ensure that the right discharge is achieved at the head of the conveyance channel (Crook 1997). Historically, only few bisses shared the same guard; this practice has become more common with improved transport and communications. In these cases, a guard phones an HEP pumping station after daily inspection of bisses to regulate discharge in channels.

Underground irrigation networks associated with HEP development require both large- and small-scale storage facilities. Newly formed consortages manage distribution from reservoirs for the larger storage facilities. Thus, traditional consortages (eg, for the Grand Bisse de Lens) have taken on new roles as service providers. This has created a second tier in bisse hierarchies, although there is often overlap between consortage membership (Crook 1997). Excess water supplies can also lead to additional consortages being formed, as was the case with the Bisse de Briey.

\section{Economic incentives}

The principal promoters, facilitators, and recipients in the HEP development process are shown in Figure 4. It is interesting to note the overlapping roles of the different political players in the process of HEP development and how financial support flows to traditional irrigation associations. This often amounts to a major financial outlay. For example, in the 1920s, the new Bisse de Briey received two significant financial contributions for the installation of two suspended pipes across the Navisence Gorge and construction of a new conduit. The HEP company and canton each provided around $25 \%$ of these funds, with the consortage contributing the remainder of these costs (Département de l'Intérieur 1929).

Financial interventions for irrigation were part of a wider effort to improve agriculture in the Valais during the late 19th and early 20th centuries (Loup 1965). The number of agricultural and HEP improvements made with financial assistance from the cantonal land improvements service to areas with spring and autumn pastures in the Bas-Valais was very large (CHF 205 million) from 1945 to 1975 (Office Fédéral de l'Agriculture 1983). A similar but lower rate of intervention also applied to the Haut-Valais from 1929 to 1961 (Loup 1965). Even after subsidies, the remaining proportion can still be beyond the range of a normal reserve fund held by a consortage. In these cases, the consortage will normally apply to the land register for agricultural credit in the form of an interest-free loan paid off over an agreed-upon period of time. This enables the consortage to raise funds by increasing water tariffs through annuities paid by members.

Contracts agreed by the State were of financial benefit to some communes and consortages due to concession taxes, annual rental charges, annual rates, cadastral taxes, communal taxes, and taxes on personal estates. Land sales, new housing, new roads, and cheap 
electricity also benefited these institutions and their members, and the Grande Dixence S.A. even built a new church for the commune of Hérémence to compensate for the disruption caused during dam construction (Crook 1997).

The concession tax-two examples: The concession tax is a less obvious form of benefit. For example, water distributed to the Grand Bisse de Lens is supplied on the condition that the grande bourgeoisie (local council) maintains the bisse and distributes the water at their cost. Allowances are made where the cost of this maintenance is too onerous. All spare water in the Liène is given over to the production of electricity, but the HEP company guarantees to pay a daily indemnity for loss in bisse discharge. The indemnity will not be paid, however, if a natural catastrophe, war, strikes, or sabotage cause interruptions in supply (consortage archives). In the event of water shortages, all bisses taking water from the Liène will have their supplies reduced in the same proportions. In the case of the grande bourgeoisie not requiring the maximum discharge of water, the HEP company pays pro rata for the use of this water. The resale price of this trade-in is based on the previous year's Swiss Consumer Price Index (per $100 \mathrm{~L} / \mathrm{s}$ : CHF 15 in 1952, CHF 32.25 in 1982-1987, CHF 43.25 in 1995). Water resale to the La Lienne S.A. forms the second most important part of the Grand Bisse de Lens consortage's annual income (around 20\%), while water sales to the four communes it serves constitute the principal source (around 75\%) of income (Crook 1997). In accordance with the convention, the grande bourgeoisie transferred these rights and conditions to the consortage of the Grand Bisse de Lens in 1980 after statutory changes (consortage archive).

Unlike the parties involved in the Liène River example, the Nendaz bisse consortages receive no monetary compensation if the HEP company fails to supply the agreed amount of irrigation water, nor are they paid for resale of this water to the HEP company.

\section{Discussion}

HEP development and wider structural adjustments to the local economy led to construction activity and improvement of many road and rail links in the Valais during the 20th century. Improved access allowed many farms to modernize, rationalize, specialize, mechanize, and improve irrigation efficiency (Loup 1965; Crook and Jones 1999b). Bisses integrated into HEP networks had their water security reinforced, and storage systems became a feature of new distribution systems. An extension to the existing bisse infrastructure and irrigated area also occurred in some areas (Crook 1997). The non-profit-making statutory role of consortages meant
FIGURE 4 Units of government and management involved in the process of HEP development and in the allocation of related financial benefits.

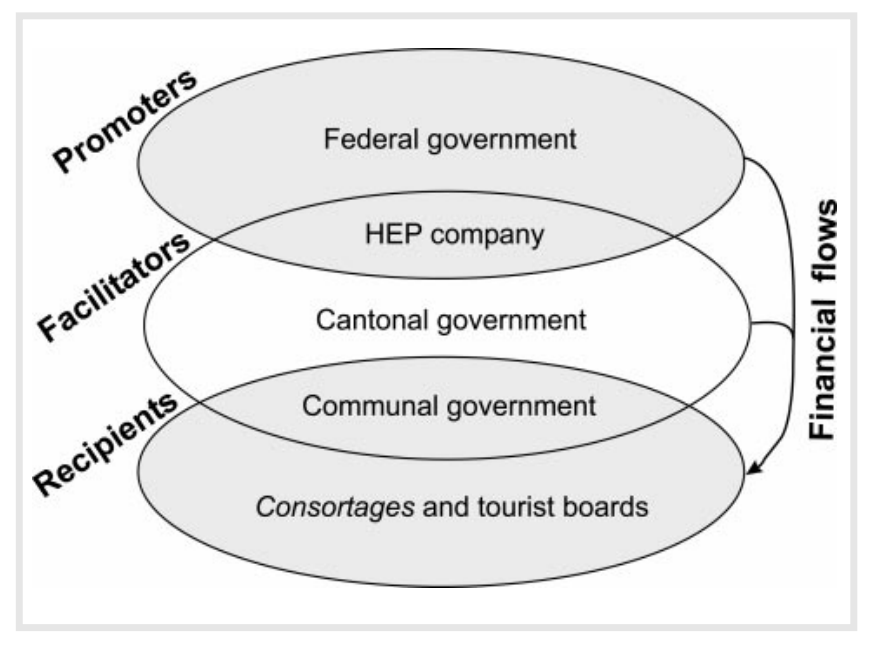

that any money generated from HEP conventions could only be used to cover operational costs and improve water distribution.

HEP companies also provided new and alternative employment opportunities to agriculture, allowing families to develop new work contingency plans, which reduced their reliance on agricultural livelihoods. Many isolated communes were opened up to mass tourism (particularly winter tourism), sometimes resulting in rapid and spectacular economic development (Park 1980; Reynard 1999). Thus, on the one hand, HEP development led to the abandonment of bisses and more specifically of agriculture, but these changes have been buffered by favorable physical and socioeconomic changes. On the other, HEP development protects consortage/communal agricultural interests where these remain economically viable. In the latter part of the 20th century, the important role of traditional irrigation in shaping the bucolic and idyllic "chocolate box" rural landscape has been recognized (Crook and Jones 1999a; Reynard 1998), with bisses promoted and regenerated by communal tourist boards in a bid to promote summer ecotourism (see Figure 1).

The unlimited duration of consortages and robust water rights demonstrating seniority and prescription made court rulings on disputes predictable and certain (Riedmatten and Zimmermann 1950). This initial interconsortage/intercommunal consultation process was a precursor to the successful formulation of conventions with EOS and subsidiaries. Periodic concession allows consultation and renegotiation between all stakeholders, which retains a level of local political decisionmaking that still has its roots in popular consensus. While the effects on downstream users have been recognized and addressed during environmental impact assessments (EIA) in other countries (Ovesen 1994; Salman and Uprety 1999), the rights of people living on 


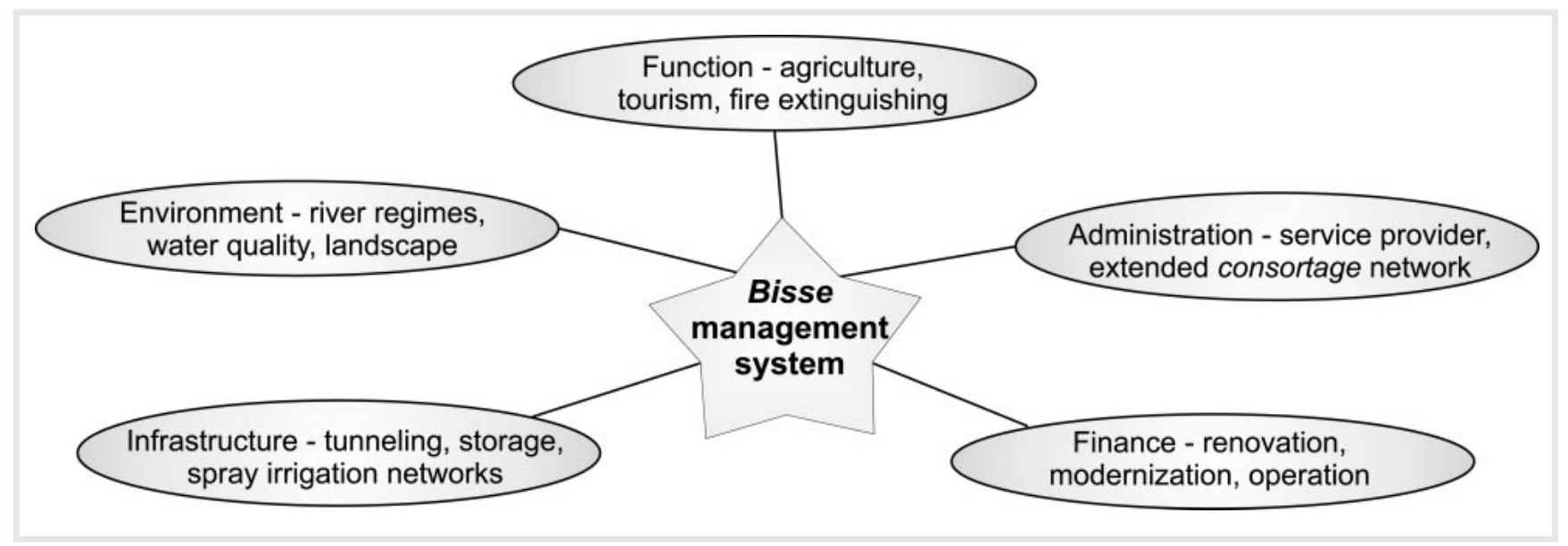

the slopes of the immediate HEP catchments are too often overlooked in the planning process. This was not the case in the Valais, as the construction of HEP dam schemes was achieved with the same inter- and intracommunal cooperative spirit that helped to construct bisses. This supports the view that participatory or informal evaluation of development programs and projects should be used to strengthen endogenous institutions (Ariyabandu 1997).

\section{Bisses, HEP, and climate change}

There is evidence to suggest that the gradual shrinking of glaciers, particularly in catchments where glaciers cover less than $10 \%$ of the area, will result in highly variable and reduced flows from glacial meltwater streams (Chen 1990). Where there is no HEP river regulation in Switzerland, the models of climate change (Houghton et al 1990; Rotmans et al 1994) suggest that bisses may suffer from problems of inadequate supply, although modern headworks are generally efficient at capturing water. In particular, bisses taking water from nonglacial streams have suffered far more from disruption as a result of water shortages during dry periods (Bratt 1995; Crook 1997). Regulation of most catchments by HEP companies may reduce the impact of potential problems caused by climate change, as stored water is less urgently needed for energy production (Garr and Fitzharris 1994). Thus, HEP storage facilities are likely to have a surplus that can be used for irrigation.

Climate change may also result in the need to connect new sources, possibly including the search for water from different watersheds. This plausible extension of the system would incur large capital costs because of the large-scale engineering works required. This work would most likely be linked into the existing HEP network and involve tunneling and underground piping rather than traditional bisse channels, particularly as climate change may cause more disruption to open bisses from hazards such as rockfall. The increased costs of maintenance will conflict with the cantonal government's predicted desire to reduce financial subsidies to bisse consortages (Crook 1997). The cantonal land improvements service, however, will provide financial support to regenerate moribund or abandoned bisses where primary (eg, agriculture) or secondary (eg, HEP) objectives can be identified by the governing bodies (Michelet 1995; Reynard 1998; Crook and Jones 1999a).

\section{Conclusion}

During the 20th century, HEP development has led to abandonment of bisses, but it has also generated improved water security for bisses for which institutional and physical structures have been improved to suit innovation in other parts of the livelihood system. Economically speaking, partial or total system abandonment can be a positive rather than a negative consequence of HEP development. A bisse will survive economically only where it provides real livelihood opportunities at the household level. Conventions between communes/ consortages and HEP companies exist for all areas of the Valais where irrigation remains a priority in HEP-controlled catchments. Thus, the integration of small-scale irrigation systems with large-scale HEP schemes dependent on the same single resource base can be achieved as long as multiobjective irrigation strategies are followed (Figure 5). This means that, where irrigation remains economically feasible, HEP development will enhance rather than threaten the sustainability of bisses. The lesson learned here is that HEP companies must recognize, respect, and adhere to preeminent traditional water rights, with local people being allowed full representation and 
involvement in the consultation process and construction of dam schemes. This level of involvement and expertise is unlikely to be met in all developing coun- tries constructing HEP schemes in areas with extant indigenous irrigation systems.

\section{AUTHOR}

\section{Darren S. Crook}

Department of Geography, University of Liverpool, Roxby Building, Liverpool L69 3BX.dcrook@liv.ac.uk

\section{ACKNOWLEDGMENTS}

D.S. Crook acknowledges a University of Huddersfield Research Studentship and a grant from the Dudley Stamp Memorial Fund. The author is extremely grateful for the help and support of numerous Valaisan farmers and officials, particularly Mr Martial Barras and Mr Nicolas Rey. Special thanks also to Dr Anne Jones and Dr Chris Hunt at the University of Huddersfield for their helpful comments on an earlier draft of this paper and their invaluable academic support.

\section{REFERENCES}

Ariyabandu MM. 1997. Use of formal and informal evaluation in institutional strengthening: the case of a village hydro project in Sri Lanka. Knowledge and Policy 10(1-2):97-108.

Bonifay J. 1997. Hydro scheme of superlatives. Sulzer Technical Review 3:6-9.

Bratt G. 1995. The Bisses of Valais: Man-made Watercourses in Switzerland. Huddersfield: Amadeus Press.

Carrier EH. 1932. Water and Grass. London: Christophers.

Chen JY. 1990. Changes of Alpine Climate and Glacier Water Resources [PhD dissertation 9243]. Zurich: Eidgenössische Technische Hochschule. Crook DS. 1997. Sustainable Mountain Irrigation? The Bisses of the Valais, Switzerland: A Holistic Appraisal [PhD thesis]. Huddersfield, UK: University of Huddersfield.

Crook DS, Jones AM. 1999a. Traditional irrigation and its importance to the tourist landscape of the Valais, Switzerland. Landscape Research 19(1):49-65.

Crook DS, Jones AM. 1999b. Design principles from traditional mountain irrigation systems (bisses) in the Valais, Switzerland. Mountain Research and Development 19(2):79-99.

Département de l'Environnement et de l'Aménagement du Territoire

(DEAT). 1995. Délimitation des zones et des périmètres de protection des eaux souterraines. Sion, Switzerland: État du Valais.

Département de I'Intérieur. 1929. Message concernant la loi sur l'amélioration des moyens d'irrigation dans le Canton du Valais. Service Cantonal des Améliorations Foncières 10/5/1929.

Énergie de l'Ouest-Suisse (EOS). 1995. EOS Energy Sources in Western Switzerland. Lausanne: Société Anonyme Énergie de l'Ouest-Suisse. Garr CE, Fitzharris BB. 1994. Sensitivity of mountain runoff and hydroelectricity to changing climate. In: Beniston M, editor. Mountain Environments in Changing Climates. London: Routledge, pp 366-381. Grande Dixence S.A. 1993. Le projet Cleuson-Dixence. Revue technique Suisse 6:37-52.

Houghton JT, Jenkins GJ, Ephraums JJ, editors. 1990. Climate Change: The IPCC Scientific Assessment. Intergovernmental Panel on Climate Change (IPCC). Cambridge: Cambridge University Press.

Jones AM, Hunt CO, Crook DS. 1998. Traditional irrigation strategies and their implication for sustainable livelihoods in semi-arid areas: examples from Switzerland and the Maltese Islands. In: Wheater $\mathrm{H}$ and Kirby $\mathrm{C}$, editors. Hydrology in a Changing Environment. Volume II. Chichester: John Wiley \& Sons, pp 485-493.
Liniger M. 1980. Bisses et autres raz des Alpes Occidentales. Les Alpes 56:42-44

Loup J. 1965. Pasteurs et agriculteurs valaisans: Contribution à l'étude des problèmes montagnards. Grenoble: Allier.

Michelet P. 1995. Les techniques d'entretien des bisses. Annales

Valaisannes 70:163-174.

Netting McC R. 1981. Balancing on an Alp: Ecological Change and Continuity in a Swiss Mountain Community. Cambridge: Cambridge University Press.

Office Fédéral de l'Agriculture. 1983. Agriculture et économie alpestre dans le Valais Romand. Cadastre de la production agricole. Sion: Département Fédéral de l’Économie Publique.

Ovesen JL. 1994. Anthropological reconnaissance in central Laos: a survey of local communities in a hydro-power project area [review]. Canadian Review of Sociology and Anthropology 31(3):362-364.

Park CC. 1980. The Grande Dixence hydro-electric scheme, Switzerland. Geography 65:317-320.

Reynard E. 1995. L'irrigation par les bisses en Valais. Approche géographique. Annales Valaisannes 70:47-64.

Reynard E. 1998. Réhabilitation de canaux d'irrigation de montagne à des fins touristiques. L'exemple des bisses du Valais (Suisse). L'eau, l'industrie, les nuisances 213:50-56.

Reynard E. 1999. Gestion patrimoniale et intégrée des ressources en eau dans les stations touristiques de montagne. Les cas de Crans-MontanaAminona et Nendaz (Valais). Travaux et recherches $n^{\circ} 17$. Lausanne: Institut de Géographie, Université de Lausanne.

Riedmatten J, Zimmermann J. 1950. A Study of the Legal Status of the Poses d'Ayent. Sion: Riedmatten \& Zimmermann.

Rotmans J, Hulme M, Downing TE. 1994. Climate change implications for Europe. An application of the ESCAPE model. Global Environmental Change 4(2):97-124.

Salman SMA, Uprety K. 1999. Hydro-politics in South Asia. A comparative analysis of the Mahakali and the Ganges treaties. Natural Resources Journal 39(2):295-343.

Tung A-C. 1998. Hydroelectricity and industrialization. The economic, social, and environmental impacts of the Sun Moon power plants. In: Elvin M and Liu T-J, editors. Sediments of Time. Environment and Society in Chinese History. Cambridge: Cambridge University Press.

Veyret P. 1970. 1869-1969. Cent ans de houille blanche. Revue de Géographie Alpine 58:5-51. 